\section{Conversa com Aldyr Schlee (parte II): a criação da camisa canarinho e seu recente uso político}

Conversation with Aldyr Schlee (part II): The creation of the "canarinho" Brazilian shirt and its political use

\section{Gustavo Cerqueira Guimarães}

Universidade Federal de Minas Gerais (UFMG), Belo Hte/Brasil Doutor em Teoria da Literatura e Literatura Comparada, UFMG gustavocguimaraes@hotmail.com

\section{Aldyr Garcia Schlee}

Universidade Federal de Pelotas (UFPel), Pelotas/Brasil

Doutor em Ciências Humanas, UFRGS

\section{Giulia Piazzi}

Centro Federal de Ed. Tecnológica (CEFET-MG), Belo Horizonte/Brasil

Mestra em Estudos de Linguagens, CEFET-MG
Resumo: Entrevista com Aldyr Schlee, escritor, jornalista, professor e desenhista, criador do uniforme da seleção brasileira de futebol, em 1953, realizada por Gustavo Cerqueira e editada por ele, em parceria com Giulia Piazzi. Neste diálogo do escritor com a revista FuLiA / UFMG, o foco é a criação do desenho da camisa canarinho e seu recente uso político nas manifestações populares, vinculadas ao golpe.

Palavras-Chave: Aldyr Schlee; Futebol e memória; Desenho; Futebol e política; Camisa da seleção brasileira.

ABSTRACT: Interview with Aldyr Schlee, writer, journalist, teacher and designer, creator of the uniform of the Brazilian football team, in 1953, made by Gustavo Cerqueira Guimarães and edited by him, in partnership with Giulia Piazzi. In this dialogue of the writer with the magazine FuLiA / UFMG, the focus is the creation of the design of the "canarinho" Brazilian shirt and its recent political use in the popular manifestations linked to the coup d'etat.

KeYwordS: Aldyr Schlee; Football and memory; Drawing; Football and politic; Brazilian national team shirt. 
Aldyr Garcia Schlee, Chilê, pronúncia aportuguesada, nasceu no dia 22 de novembro de 1934, em Jaguarão/RS, uma pequena cidade ao extremo sul do Brasil, na divisa com Río Branco. É jornalista, tradutor, livredocente, aposentado pela Universidade Federal de Pelotas/RS, onde lecionou, dentre outras disciplinas, Direito Internacional, desenhista e escritor. ${ }^{1}$

Encontrei-me com o Schlee em sua casa, em Pelotas, no dia 15 de maio de 2017, segunda-feira, às $10 \mathrm{~h}$ de uma manhã bastante fria. Primeiramente, trocamos algumas mensagens por e-mail intermediadas pelo Luiz Heron da Silva e pelo Alfredo Aquino, seu editor, a quem agradecemos.

Antes de iniciar a gravação de grande parte de nossa conversa, fizemos um preâmbulo de uns 20 minutos

\footnotetext{
${ }^{1}$ Schlee estreou na literatura com Contos de sempre (1983) e, dentre muitos outros livros de destaque, publicou $O$ dia em que o Papa foi a Melo (1999), adaptado para o cinema com o título El baño del Papa (2007), e Os limites do impossível: contos gardelianos (2009), que narra histórias interligando dramas de mulheres de distintas nacionalidades, racas, idades e classes sociais. Outras obras de Schlee: Uma terra só (1984), Linha divisória (1998), Contos de verdades (2000), Don Frutos (2010), Contos da vida difícil (2013), Memórias de o que já não será (2014) e Fitas de cinema (2015).
}

a fim de estabelecermos os rumos que a entrevista tomaria. Logo, percebemos que estávamos bem à vontade um com o outro, afinal de contas, falar sobre futebol aproximam as pessoas, não é mesmo?

Assim, o que seria uma entrevista passou a se configurar como uma conversa, uma prosa que, a seu convite, estendeu-se até o Mercado Central de Pelotas para o almoço, onde pude perceber ainda mais 0 quanto o Aldyr é uma pessoa elegante, simples e de uma erudição admirável, atributos que igualmente se aplicam à sua literatura.

Apesar do papo fluido, cerca de duas horas, os três assuntos motivadores do encontro foram contemplados: o futebol local; ${ }^{2}$ o livro, de sua autoria, Contos de futebol (1997); ${ }^{3}$ e a criação do desenho do uniforme da seleção brasileira de futebol.

\footnotetext{
${ }^{2} \mathrm{O}$ futebol é colocado diretamente em contato com questões relativas às fronteiras (Jaguarão/Brasil e Río Branco/Uruguai e Lajinha/MG e Ibatiba/ES). Conf.: "Conversa com Aldyr Schlee (parte I): futebol local e narrativas de fronteiras", FuLiA / UFMG, 2017 http://bit.ly/FuLiA-UFMG-schlee-fronteiras.

${ }^{3}$ Entrevista em fase de edição a ser publicada com o seguinte título: "Contos de futebol: conversa com Aldyr Schlee (parte III)".
} 
Do ponto de vista formal, uma de nossas preocupações foi a de manter o caráter oral da entrevista, sua performatividade, sem, contudo, perder o rigor da escrita. Para tanto, foi preciso cortar trechos repetitivos, ligar as frases com conectivos mais precisos e acrescentar algumas referências, datas e notas.

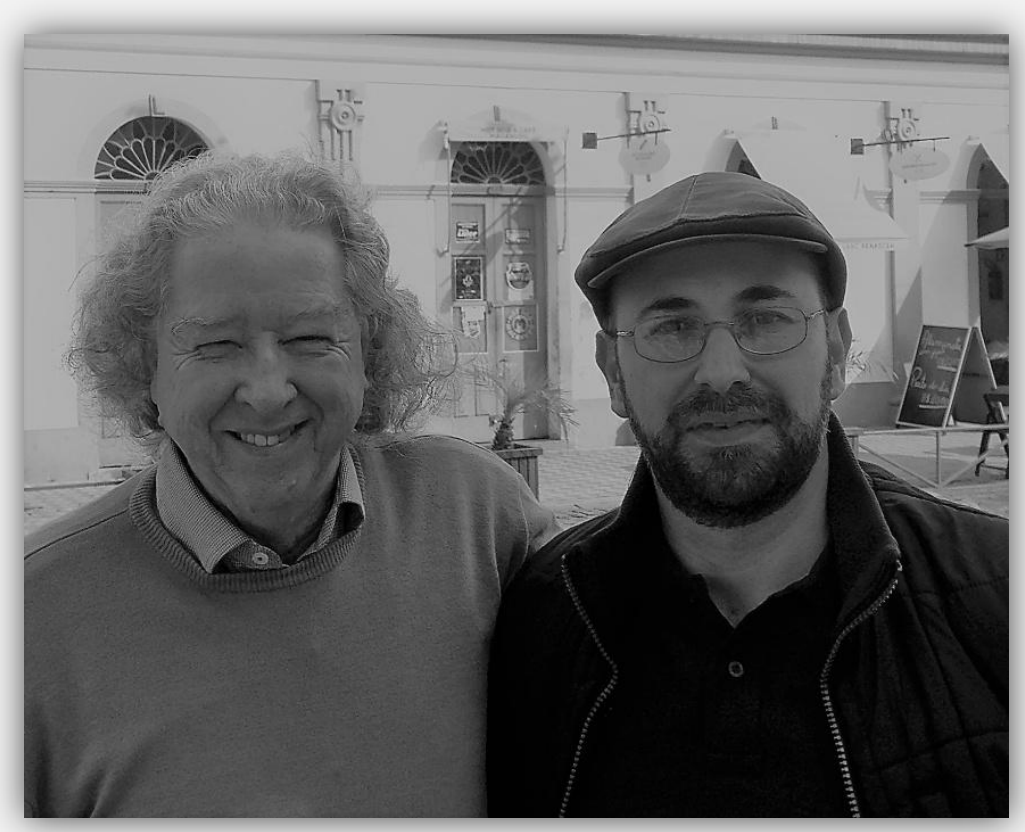

Aldyr Schlee e Gustavo Cerqueira, Pelotas, 15 maio 2017. Fotografia: Angélica Freitas.
Gustavo Cerqueira Guimarães: Gostaria de falar sobre o seu desenho do uniforme da seleção brasileira de futebol, criado em 1953, para o concurso que elegeria os novos trajes para disputa da Copa do Mundo de 1954, na Suíça. ${ }^{4}$ Eu assisti ao seu filho dando um depoimento no curtametragem Gaúchos carinhos (2007),5 onde ele falava: "meu pai nunca deu muita importância pra camisa da seleção brasileira". É isso mesmo?

Aldyr Garcia Schlee: É isso sim, pois só agora eu estou dando mais importância à camisa que eu criei. 0 2o colocado do

\footnotetext{
${ }^{4}$ No Mundial anterior, o escrete havia sofrido sua mais trágica derrota esportiva, em casa, para o Uruguai, conhecida como Maracanazo. Na ocasião, a seleção vestia um uniforme predominantemente branco com detalhes em azul, que não expressava a vibração do país, segundo o edital do concurso. Para mudar isso, o periódico carioca Correio da Manhã promoveu, com o aval da Confederação Brasileira de Desportos, o concurso de desenhos, solicitando que fossem utilizadas as quatro cores da nossa bandeira. Desde então, a Canarinho, de Aldyr Schlee, tornou-se um símbolo fortíssimo da identidade brasileira, sobretudo a partir dos anos 1970, por conta do título no México (e primeira Copa exibida a cores), e 1990, quando da profusão de camisas futebolísticas pelo mundo, com destaque para a canarinho.

5 Documentário de Rene Goya Filho sobre a criação da camisa da seleção brasileira de futebol. Produzido por Estação Elétrica Filme e Vídeo e RBSTV. Filme completo: bit.ly/FuLiA-gauchos-canarinhos.
} 
concurso era desenhista da Casa da Moeda e tinha criado o cartaz da Copa de 1950, ultraprofissional, o que me enche de razão, poxa, eu ganhei desse cara, né (risos), me tira qualquer dúvida. 0 meu trabalho era um trabalho profissional, apesar de guri, de ser um cara de 18 anos, eu não tinha feito 19.

Gustavo: Pois é, vim aqui pra falar sobre futebol e sobre a camisa da seleção, porque eu acho muito singular você, em 1953, novinho, morando no sul, vencer o concurso no meio de tantos desenhos; ou seja, não foi peixada, né (risos). Eu realmente acho isso grandioso, a camisa se tornou um símbolo forte do Brasil, e pensar como ela está sendo usada, hoje, nas ruas, vamos falar disso quando quiser...

Schlee: Perfeitamente. Uma coisa curiosa que há sobre a camiseta é que, infelizmente, não tem a relação de todos que concorreram. Eu soube que desde o início foram 301 candidatos, 100 deles, não corresponderam às exigências do regulamento, ou desenharam a lápis, preto e branco, ou não botaram as quatro cores, que o regulamento previa, ou não usaram o suporte $30 \times 40$. Eles não foram nem contabi- lizados entre os que concorreram. Ficaram, então, 200, 201, que certamente cumpriram com os requisitos, o que também acho que incluiu muito amador.

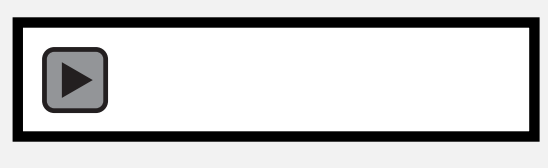

Áudio 1: trecho da entrevista. ${ }^{6}$

Link: http://bit.ly/FuLiA-UFMG-schlee-camisa-inventor.

Fiz um trabalho muito cuidadoso e eu me orgulho desse desenho, um desenho feito sobre uma plataforma de cartão $30 \times 40$, colorido, e bem colorido, porque eu utilizei a figura de um jogador, isso é pouco divulgado, de um jogador em ação... [a filha de Schlee entra e sai...] esse jogador Índio, do São Cristóvão, saiu em preto e branco numa fotografia, em ação, publicada na contracapa do Esporte Ilustrado no primeiro semestre de 1953.

Gustavo: Foto do seu desenho?

\footnotetext{
${ }^{6}$ Importante: para ouvir o áudio é necessário baixar este PDF para o computador, recomendamos o uso do Adobe Reader ou Foxit.
} 
Schlee: Não, não era meu desenho, era a foto do Índio. Aí, quando eu me convenci de que eu deveria participar do concurso. Primeiro, eu não ia participar porque achei que era muito exagero quatro cores. A ideia que me ocorreu ao ler o regulamento, logo, foi a de que quatro cores tinham que estar na camiseta. Não havia nenhuma camiseta do mundo com quatro cores, nem o futebol africano com camisetas incríveis. As camisas eram muito bem comportadas a partir do modelo original inglês. Não havia nada que pudesse admitir quatro cores numa camiseta de futebol, não existia.

Eu achava que o concurso era sério, então eu não ia participar. Mas acontece que eu fui ao Rio, na verdade eu fui a São Paulo para um curso na penitenciária do Carandiru, Direito Penitenciário - claro que eu não fiz o curso, eu só bati umas fotos, tenho as fotos minha com os colegas, eu fiquei num hotel separado junto com uma amiga e mais dois caras, um hotel de alta rotatividade, Hotel Imperial, mas fizemos, eu e dois amigos meus, fizemos os três uma série de reportagens durante o curso, de reportagens free- lancer nas folhas de São Paulo. Foram publicadas três reportagens e ainda tivemos a oportunidade de conhecer o candidato ao governo do Estado do Rio Grande do Sul que estava por lá fazendo uma reportagem para o diário dos associados, inédita e tal.

0 resultado disso é que ganhamos um dinheiro suficiente pra ir pro Rio, e num sábado de tarde fomos ver um jogo não me lembro de quem, não tenho anotado, com a Portuguesa Carioca. Não sei se era Botafogo, era um time grande, era Maracanã com a Portuguesa Carioca, não tenho essa anotação e não procurei saber... resultado, quando entra em campo a Portuguesa Carioca, ela estava de camisa verde e, atenção, calção vermelho (risos), calção vermelho, como calção vermelho?!

Então eu era o escritor, o redator dos textos dessas reportagens, o cara que abria, que era peitudo à beça, Roberto Xavier, um colega nosso que usava revólver na cintura, um cara maluco, mas ao mesmo tempo capaz de enfrentar o impossível pra conseguir alguma coisa, e o fotógrafo era o 
Moisés, um judeu grandão, que também estudava aqui, mas era de Porto Alegre.

Nós, os três, fizemos essas reportagens, ganhamos dinheiro e fomos pro Rio. Fomos ver o jogo, e eu me encantei: mas como calção vermelho? Da onde, com que tecido? Só havia calção preto que ficava logo cinza, calção azul zuarte, calção de zuarte que durava, e branco.

Aí, eu me dei conta: é só usar uma cor no calção e fazer uma combinação boa de verde e amarelo. Primeiro, eu fiz cento e tantos bonecos, que eu tenho até hoje, com as mais absurdas relações entre as cores, as combinações não importam se eram feias, o quê que eram... eu pintei, e acabei com a certeza seguinte: que a meia e o calção são neutros em relação ao fardamento. Ou seja, a meia não tem nada que ver com a cor do clube, necessariamente, o calção não tem nada a ver com a cor do clube.

O Flamengo, que é rubro-negro indiscutível, o Flamengo tem calção branco sempre, eventualmente não, e isso não transforma o Flamengo em tricolor. 0 Botafogo, queridís- simo da época, meias cinzentas. 0 Botafogo é preto e branco, o famoso alvinegro de General Severiano.

Então eu me senti à vontade pra trabalhar o verde e o amarelo como cores fundamentais e botar no calção e na meia as cores complementares que não iam mudar... me casei com o verde e amarelo, fiquei com o verde e amarelo, fiz todas as bobagens com o verde e amarelo, faixa atravessada, riscada...

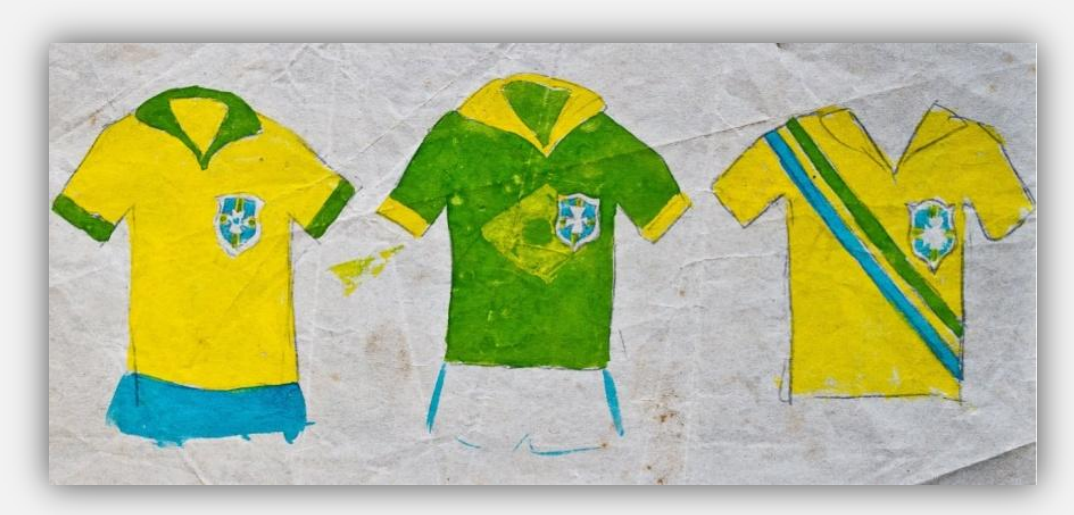

Modelos das camisas feitas por Schlee (1953). Fotografia: Gilberto Perin.

E quando eu me dei conta de que, ao contrário da bandeira nacional, que é verde, e o amarelo é só o losango, era possí- 
vel criar uma camiseta representativa do Brasil: amarela com detalhes apenas em verde, porque o amarelo com azul ficava muito bonito, ao contrário do verde, que seria papagaiada também na camiseta, era demais... e o calção branco ficava mal ou, como joga às vezes a seleção, camisa amarela e calção branco, que aí acerta a cena. Nesse momento, eu me senti habilitado pra fazer o desenho.

Peguei então a figura do Índio, copiei a figura do Índio, marquei numa câmara clara deste tamanho, marquei na câmara clara onde eu botei a cópia da contracapa, marquei as sombras e marquei todos os detalhes da musculatura da perna, do braço, da cara do jogador, só botei um bigodinho depois pra descaracterizar o jogador, era a época do bigodinho, mudei um pouco o cabelo dele e pronto, daí eu colori, fiz todo o fundo do Maracanã em sépia, tudo em sépia, o chão em sépia, tudo, o céu em sépia, não, o céu não aparece, tudo em sépia e só colori o jogador...

0 resultado disso foi um desenho muito bonito, muito bonito. Eu tive um grande prazer em fazê-lo. Sinto muito orgulho, até, se é possível a gente alimentar orgulhos, né, por ter ganho o concurso. E o resultado foi aceito com muita alegria também pelos organizadores, houve unanimidade.

Gustavo: Até hoje, né, até hoje...

Schlee: Pois é... na comissão julgadora, integrada por gente que conhecia a arte, pessoal da Escola Nacional de Belas Artes, ilustradores, que não concorreram no concurso, além de representantes dos jornais, o patrocinador do concurso, que era o Correio da Manhã, que me deu os prêmios, e $O$ Globo, que não queria a mudança, porque a ideia era de outro, mas $O$ Globo acabou participando com seu representante na comissão, e houve unanimidade.

Gustavo: E a premiação na época foi o quê, além de você ir morar no Rio por isso?

Schlee: É... 40 mil. Hoje, podemos pensar que seria o equivalente a um carro pequeno, então não tá longe desses 40 , por aí... 


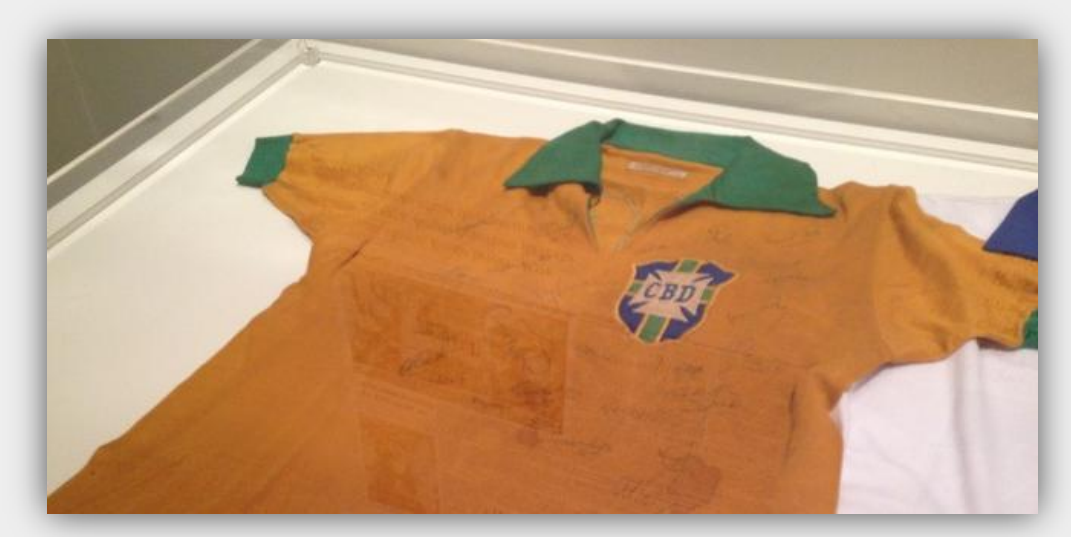

Camisa canarinho de 1960 igual ao modelo original. Foto: Vinícius Guerreiro. Fonte: GE - https://glo.bo/2LzSGr6.

Gustavo: Foi um bom dinheiro, né?

Schlee: Foi um bom dinheiro, que entreguei pro meu pai todo, sem nada; um estágio no Correio da Manhã, na área de ilustração - pois ele não era ilustrado. Aliás, nenhum jornal era ilustrado. O Correio da Manhã pretendia ser ilustrado a partir de agosto daquele ano (1954, eu ganhei o concurso em dezembro de 1953). Então, fui pro Rio e comecei a desfrutar do prêmio do Correio da Manhã, não imediatamente iniciei a desenhar coisas lá no Correio, mas já desfrutando de um hotel com tudo pago, tudo, tudo pago.

\section{Gustavo: Durante um ano?}

Schlee: Não, não, durante o período de estágio, que era de seis meses. Então, isso foi muito bom. Muito bom.

Gustavo: com 19 anos você já se sentia como um profissional, já reconhecido, né, podendo fazer um excelente estágio.

Schlee: Foi um achado eu ficar num hotel perto do trabalho. Isso pra mim foi muito importante. E, imediatamente, eu passei à concentração da seleção brasileira para o jogo com o Chile, que o Brasil ganharia por 1 a 0 . Depois, houve denúncias de que havia muita safadeza no ambiente da seleção, e havia mesmo, eu sou testemunha disso.

Isso me fez me decepcionar muito com a estrutura toda que mantinha o futebol profissional no Brasil. Me decepcionei muito. Depois, não quis ir à Suíça pra acompanhar a seleção. Eu me sentia até com medo de alguns jogadores ou dos jogadores em geral, eu era de formação metodista, imagina, um puritano. 0 resultado foi que me choquei muito com aquilo, né.

Gustavo: Mas por que dos jogadores? 
Schlee: Pela denúncia de que havia muita safadeza na concentração em São Januário, nós fomos pro alto da Gávea, lá pra mansão de um deputado.

\section{Gustavo: Safadeza era o quê?}

Schlee: Agora eu conto. Na concentração do Flamengo, os jogadores passavam a noite no quarto do Didi jogando carta. A fumaceira - eu não fumava, nunca fumei - era insuportável. A fumaça saía por baixo das portas, no corredor, mal iluminado, e um dos massagistas, Mário Américo, cuidava para que o supervisor, que depois seria técnico, que era da seleção, Paulo Amaral, não aparecesse.

Mas eu acho que o Paulo Amaral sabia de tudo, e o técnico Zezé Moreira, com certeza fazia que não sabia. 0 Zé Moreira era um animal. Ele agrediu no vestiário o Humberto, jogador do Palmeiras, que, por sua vez, tinha agredido um repórter. Os chuveiros do Maracanã estavam longe das banheiras térmicas de hoje.

Os chuveiros tinham uma portazinha que nem de filme de faroeste, vai e vem, e um jornalista da rádio Panamericana, se não me engano, vem entrevistar o Humberto, no chuveiro, ensaboado, e fez uma pergunta que eu não sei, não foi divulgada, pro Humberto, que achou que ficava comprometido por ter sido o primeiro jogador na história do futebol brasileiro substituído durante um jogo. Naquele ano, foi admitida a regra 3 , da substituição, e o Humberto foi substituído, estava muito chateado com isso, porque era altamente denegridor. Então ele empurrou a porta na boca do jogador, e sangrou. E eu lá perdido no meio...

Gustavo: Como é que é?

Schlee: O Humberto... estourou a boca, dente, nariz, tudo do cara, que estava na porta com o microfone de rádio. Aí, houve aquele tumulto, eu estava no meio daquela... o vestiário enchia de gente, políticos, era isso, aquilo, o Brasil ganhou... não sei o quê. E eu estava ali, meio perdido, porque eu estava sempre meio perdido nesse espaço, muito a contragosto. E o resultado é que o Zezé Moreira passou perto de mim, correndo, com um par de chuteiras na mão, presos pelos cadarços, foi o que eu vi. E logo adiante aconteceu o 
que me contaram depois, que ele bateu no Humberto com o par de chuteiras na cara, na cara. Esse era o ambiente, de nervosismo, hostil.

Já em São Januário, os apartamentos eram pra três, pra quatro pessoas. Era a cama com uma sobrecama em cima, dois, uma em cima e outra embaixo. Lá em São Januário, eu fiquei junto com dois jogadores gaúchos, porque eu era gaúcho, então me colocaram junto com o Paulinho de Almeida, que tinha sido do Internacional e era do Vasco, já na seleção, e com um centromédio, acho que Salvador, que ainda era do Internacional na época. Dois gaúchos e um guri gaúcho, o "Gaúcho", como eles me chamavam.

Depois, com essa confusão toda, fomos pras paineiras lá em cima, na mansão de um deputado. Aí, aconteceu um episódio particular, um episódio isolado, mas muito sério: o Pinheiro, que bebia muito, deu a chave do Cadillac conversível dele, e um amigo levou lá pras paineiras, estacionou debaixo de um pé de três-marias. E o cara, durante a noite, o Pinheiro desceu, se arranhou todo, porque essa planta tem espinhos, e entrou no carro e foi pra farra. Às 4 horas da manhã estava voltando, provavelmente bêbado, e bateu no paredão da direita, subida pra Gávea, quebrou o nariz, e não aconteceu mais nada de grave. Chegou, então, às $4 \mathrm{~h} 30$ com o nariz quebrado. No outro dia, de manhã, na hora do café, nós todos soubemos que ele tinha quebrado o nariz escorregando no banheiro, e só mais tarde, claro, passou a verdade, mas não foi divulgada pela imprensa.

Os funcionários, vamos chamar assim, os garçons e copeiros da mansão onde estávamos hospedados. Ofereceram, como já tinham feito os funcionários de São Januário, mulheres pra atender as necessidades fisiológicas dos jogadores (risos). Resultado: às 2 horas da tarde, era hora da sesta, os santinhos iam sestear, só que eles pediam pra um cara como eu que ou aceitasse botar três mulheres ou saísse pra facilitar as coisas pra eles (risos).

Nessas circunstâncias, havia constrangimento pra mim, e ao mesmo tempo um desgosto muito grande por ver como era a coisa, né. Porque não era apenas pelo comportamento, 
digamos, mau comportamento dos jogadores, era exigir muita coisa, era ter muito preconceito também, né, mas era como aquilo funcionava, à base da hipocrisia, do ocultismo. E havia por trás uma série de coisas, fofoca...

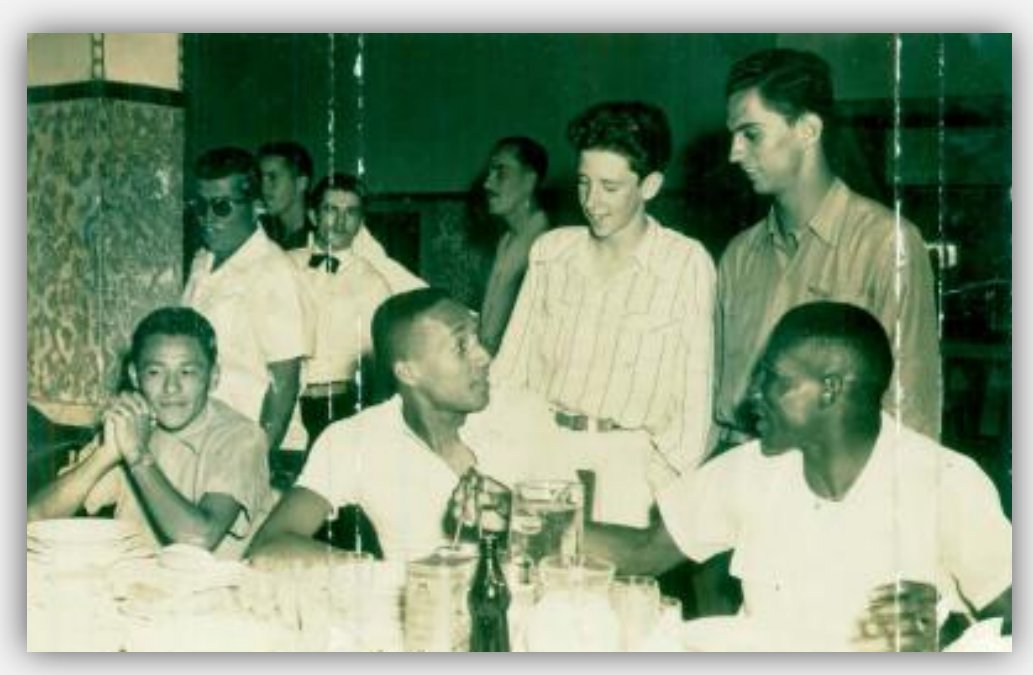

Schlee, em 1954, com Djalma Santos, Paulinho, Salvador e Dequinha, jogadores da Seleção Brasileira de Futebol. Fonte: http://bit.ly/2sR3jOs.

Eu fiquei muito desagradado com aquilo, realmente não foi um bom momento. Isso porque lá nas paineiras eu fiquei na companhia de dois caras sensacionais, o Dequinha, centromédio do Flamengo, e o Djalma Santos, jovem ainda, que depois seria, jogando uma partida, o craque da Copa de 1958. Em 1954, fracassamos... é engraçado: a famosa camisa não serviu pra nada em 1954... fomos um fiasco na Suíça, o Nilton Santos se comportou mal. Aliás, foi horrível, realmente foi muito ruim. Eu fico contente de não ter ido, porque eu ia sofrer muito com isso.

Então o que aconteceu? Eu passei a ter uma visão por dentro da organização do nosso futebol, que já era péssima, e passei a tentar esquecer o significado que se pretendia dar à camiseta, até porque lá em 1954 não funcionou.

Com isso, aconteceu aquilo que o meu filho já observou, que eu nunca dei muita atenção à camisa. Mas um jornalista escocês, Alex Bellos, que escreveu aquele livro Futebol: The Brazilian Way of Life (2002), ele me acompanhou, e tem um capítulo inteiro dedicado a essa questão do futebol brasileiro e da representação do futebol brasileiro através de um ícone indiscutível, nacional e internacional, hoje, que é a camisa. Ele me convenceu disso, né. Você fez um símbolo brasileiro, mais usado que a bandeira, está aí em 
tudo que é lugar. Naquele tempo, nas quadras de tênis, nos autódromos... não é só no futebol. A camisa que você criou é um símbolo nacional e tal.

Daí ele me acompanhou e conheceu a minha mulher também, que via dois, três jogos por dia, que era apaixonada por futebol e cinema, passava o dia inteiro desde que se aposentou vendo cinema, filmes muito bons, muito bem escolhidos, e vendo jogos em geral. Então, a minha mulher confessou pra ele que era torcedora do Galatasaray, o cara acreditou mesmo (risos), divulgou isso. Era porque naquele era o momento do Galatasaray, tinha jogadores brasileiros e tudo, né.

Mas fomos a Montevidéu os três, ele me convidou. Ele acompanhou a nossa reação toda, né. E fui me mantendo o mais que eu podia em dia com a minha maneira de encarar o futebol e com a minha maneira de ser sensível à seleção uruguaia, como velho torcedor do Uruguai, anteriormente até à criação da camisa.
O momento culminante dessa experiência foi quando tocou o hino nacional uruguaio, eu desandei a chorar porque a emoção foi forte demais pra mim. Eu então nunca mais pude renegar, acho que por mais safado que eu fosse, essa paixão futebolística pelo futebol uruguaio e particularmente pelo Nacional como time e pela seleção uruguaia, cuja camiseta eu não sei quem foi o autor (risos), mas que era bicampeã olímpica e bicampeã mundial. Então, com esses quatro títulos, que hoje pesam tanto, tanto um quanto o outro, o Uruguai, que tinha todo o tempo anterior até 1950, da minha infância e juventude, tinha sido a grande seleção da América do Sul, só encontrando par na Argentina, e sendo o Brasil apenas um parceiro menor desse trio. 0 Brasil tinha aquele complexo que o Nelson Rodrigues tanto falava, né.

Gustavo: 0 complexo de vira-lata...

Schlee: Não sei se merecido até, de modo que eu tenho muita tranquilidade, nenhuma dúvida de afirmar essa mi- 
nha paixão futebolística, que não tem que ser comprovada, não tem que ser discutida nem nada.

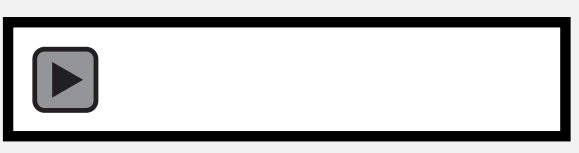

Áudio 2: trecho da entrevista. ${ }^{7}$

Link: http://bit.ly/FuLiA-UFMG-schlee-camisa-uso-politico.

E particularmente contra a camiseta, quanto à camiseta, fora o desenho, e até como eu disse, o provável orgulho que eu possa ter ou deva ter a respeito da criação, a camiseta hoje representa a corrupção neste país, representa o golpismo neste país. A corrupção, por causa do distintivo que ela leva, que felizmente não fui eu que criei e que identifica um órgão que responde pelo futebol no Brasil, que é o mais corrupto, por todas as coisas que nós sabemos.

E quanto à cor da camiseta, a camiseta em si se tornou, provavelmente por causa do verde e amarelo, símbolo do

\footnotetext{
${ }^{7}$ Importante: para ouvir o áudio é necessário baixar este PDF para o computador, recomendamos o uso do Adobe Reader ou Foxit.
}

golpismo neste país. Foi ostentando a camiseta que multidões foram às ruas apelando pela queda da presidente Dilma Rousseff, e levando ao desastre que aconteceu do ponto de vista político, com a substituição da presidente, legitimamente eleita, por um grupo de ladrões que estão no poder, se mantendo graças ao jogo político que eles fazem, cedendo cargos, comprando cargos e mantendo sempre dentro do Congresso Nacional aquilo que foi resultado do golpe congressual, o golpe que se deu dentro do Congresso pra que esses caras que estão dentro do poder, esse grupo de gatunos, ladrões, se manterem no poder.

Apesar de toda a onda de moralismo barato da pior espécie que se desenvolveu no Brasil, essas camisetas verde e amarelas não estão reaparecendo para a derrubada do bando de ladrões que aí está. Esse moralismo serviu pra sustentar, alimentar e definir o golpe, em nome de uma camiseta que eu detesto. Nesse sentido, eu não tenho nada a ver com ela, não quero ter nada a ver com ela e acho que ela foi empregada de maneira safada. 
Gustavo: Sim, mas, felizmente, os símbolos mudam, um dia isso vai mudar, vai ser reinterpretado, com certeza...

Schlee: Sim, porque ela agora, como símbolo nacional, parece que é inabalável, e isso é uma coisa curiosa. Ainda tá mais fácil mudar o governo, mudar até o Regime (risos), do que mudar a camiseta, é uma coisa impressionante. Não me passa pela cabeça...

Uma vez, há muito tempo, eu fui ao Rio de Janeiro pra uma conferência das Nações Unidas, era professor de Direito Internacional, num momento da maior perseguição... o pessoal do Jornal do Brasil, muitos amigos que eu tinha lá criaram uma oportunidade pra eu me asilar na Embaixada da Colômbia. Eu me acovardei e não fui. Eles foram comigo, pra garantir, tinha um esquema todo armado. Nesse momento, eu participei desse negócio das Nações Unidas. E durante a apresentação, quem comandava aqui no Brasil, nesse congresso, era um grande internacionalista brasileiro, de renome mundial, chamado Haroldo Valladão, que aliás foi examinador na minha tese de Doutorado, muito respeitado no mundo todo e comandando aqui no Brasil naquele momento um encontro internacional, sobre Direito Internacional, e eu estava lá entre os palestrantes, e quando estava terminando a sessão, antes do Haroldo Valladão falar, começaram a chegar representantes da imprensa, principalmente emissoras, três emissoras de televisão. Aí terminou o troço, bateram palmas, terminou tudo, a imprensa veio toda, os caras falando sobre a camiseta da seleção brasileira comigo, tchê (risos).

Aí, o Armando Nogueira, o diretor de esportes do Correio da Manhã, mandou que me perguntassem, porque eu conhecia ele desde o Diário Carioca... o Armando Nogueira mandou perguntar pra mim o seguinte: se não era oportuno mudar a cor da camiseta, e eu respondi: é mais do que oportuno. Tem que ser uma camiseta que corresponda à cor da situação que nós estamos vivendo. Qual cor? Marrom. Marrom. Não saiu no jornal (risos). Mas o Armando Nogueira escreveu um artigo sobre isso, sabe? Claro que ele entendeu que marrom era aquele, né, então ele publicou o texto. Mas é assim, só mudando pra marrom, daí 
perde o sentido, perde-se o sentido da camiseta, mas se ganha o sentido da situação.

Gustavo: Claro, está tudo marrom mesmo (risos). A amarelinha se associou à direita mais do que nunca na história política recente e está a serviço da CBF, instituição investigada por suspeita de crimes contra o sistema financeiro, falsidade ideológica e estelionato, supostamente cometidos pelos seus representantes. ${ }^{8} \mathrm{E}$ é triste constatar que a Fifa e a Conmebol andam pelos mesmos caminhos. Nicolás Leoz, preso recentemente, dirigiu a Conmebol por 30 anos. A Conmebol foi a primeira confederação de futebol do mun-

8 "O ministro Celso de Mello, do Supremo Tribunal Federal (STF), decidiu nesta quinta-feira, enviar à Justiça Federal do Rio de Janeiro uma investigação que tramita no Supremo para apurar crimes supostamente cometidos por dirigentes da Confederação Brasileira de Futebol e outras pessoas ligadas à confederação, incluindo o presidente afastado Marco Polo Del Nero e os ex-presidentes Ricardo Teixeira e José Maria Marin. O ministro manteve no STF apenas a parte referente ao deputado federal Marcus Vicente (PP-ES), que é vice-presidente da entidade. A investigação foi iniciada originalmente na Delegacia de Repressão a Corrupção e Crimes Financeiros da Superintendência Regional da Polícia Federal no Estado do Rio de Janeiro, para apurar os supostos crimes de evasão de divisas, estelionato, falsidade ideológica e crimes contra o sistema financeiro nacional". Estadão, "STF envia investigação contra dirigentes da CBF para Justiça do Rio" (http://bit.ly/2Jpr5fu), 26 abr. 2018. do, já é centenária e só teve uns oito presidentes até hoje. Sobre a Fifa, é melhor nem comentar, né.

Ainda bem que ainda existem outros tipos de futebol na vida, né, outros futebóis, o futebol de várzea, por exemplo, que está em seu livro, como uma prática de resistência (risos). É preciso resistir.

Schlee: Sim, é preciso. Podemos fazer uma pausa?

Belo Horizonte, 12 de junho de 2018 